\title{
INTRACELLULAR DIGESTION AND HYDROLYTIC ENZYMES IN THE PHAGOCYTES OF PLANARIANS ${ }^{1}$
}

\author{
ROBERT M. ROSENBAUM AND CARMEN I. ROLON
}

Department of Pathology, Albert Einstein College of Medicine, New York 61, N. Y.

It has been established that, in those species studied, intraluminar digestion does not occur in triclad flatworms (Willier, Hyman and Rifenburgh, 1925; Jennings, 1957), but that digestion takes place within food vacuoles in the phagocytic cells of the gastrodermis. A number of investigators have observed the disintegration of ingested food particles within these cells (Arnold, 1909; SaintHilaire, 1910; Jacek, 1917 ; von Levitzow, 1943), but the methods they employed did not permit elucidation of the mechanisms involved except in a most general way. Kelley (1931), studying the intracelular digestion of nucleoprotein in $D$. dorotocephala by means of the Feulgen reaction with and without acid hydrolysis, showed that the ingested material was hydrolyzed within the first two hours.

To our knowledge, no previous study has characterized the hydrolytic enzymes in the phagocytes of planarians. The present report considers the relationship of three such enzymes to current concepts of intracellular digestion.

\section{Materials and Methods}

Specimens of Dugesia dorotocephala and D. tigrina were used for this study. The animals were maintained as stock cultures at $18^{\circ} \mathrm{C}$. and fed routinely once every ten days on minced rat or mouse liver. Experimental animals were isolated in fingerbowls and starved for at least three weeks. Some of these were fed raw rat or mouse liver, and others boiled liver to determine if enzyme activities in raw food were transferred to the gut. No differences in enzyme activities between animals fed raw or boiled liver were demonstrable by the staining methods employed. The worms were observed during feeding; post-feeding times were determined from the moment the animals ceased feeding.

For the demonstration of those enzyme activities surviving chemical fixation, specimens were initially fixed in warm ( $37^{\circ}$ C.) Baker's calcium-formalin for 5 minutes to prevent discharge of the gut contents. They were then placed in calcium-formalin at $4^{\circ} \mathrm{C}$. for 24 hours, washed for 5 minutes in distilled water and cut on a $\mathrm{CO}_{2}$-freezing microtome at $8-10 \mu$. Material thus prepared was incubated for acid phosphatase activity by a slight modification of the method of Gomori (1952). Sections were incubated for 15-30 minutes in a $0.1 M 2$ glycerophosphate and lead nitrate mixture buffered to $\mathrm{pH} 5.0$ with $0.05 \mathrm{M}$ acetate buffer.

Aminopeptidase activity was visualized by the method of Burstone and Folk (1956). Animals were placed on Monel grids and frozen in isopentane chilled by liquid nitrogen to $-160^{\circ} \mathrm{C}$. After quenching, the worms were dehydrated for 24

1 This investigation was supported by a research grant, No. RG-5483, from the United States Public Health Service. 

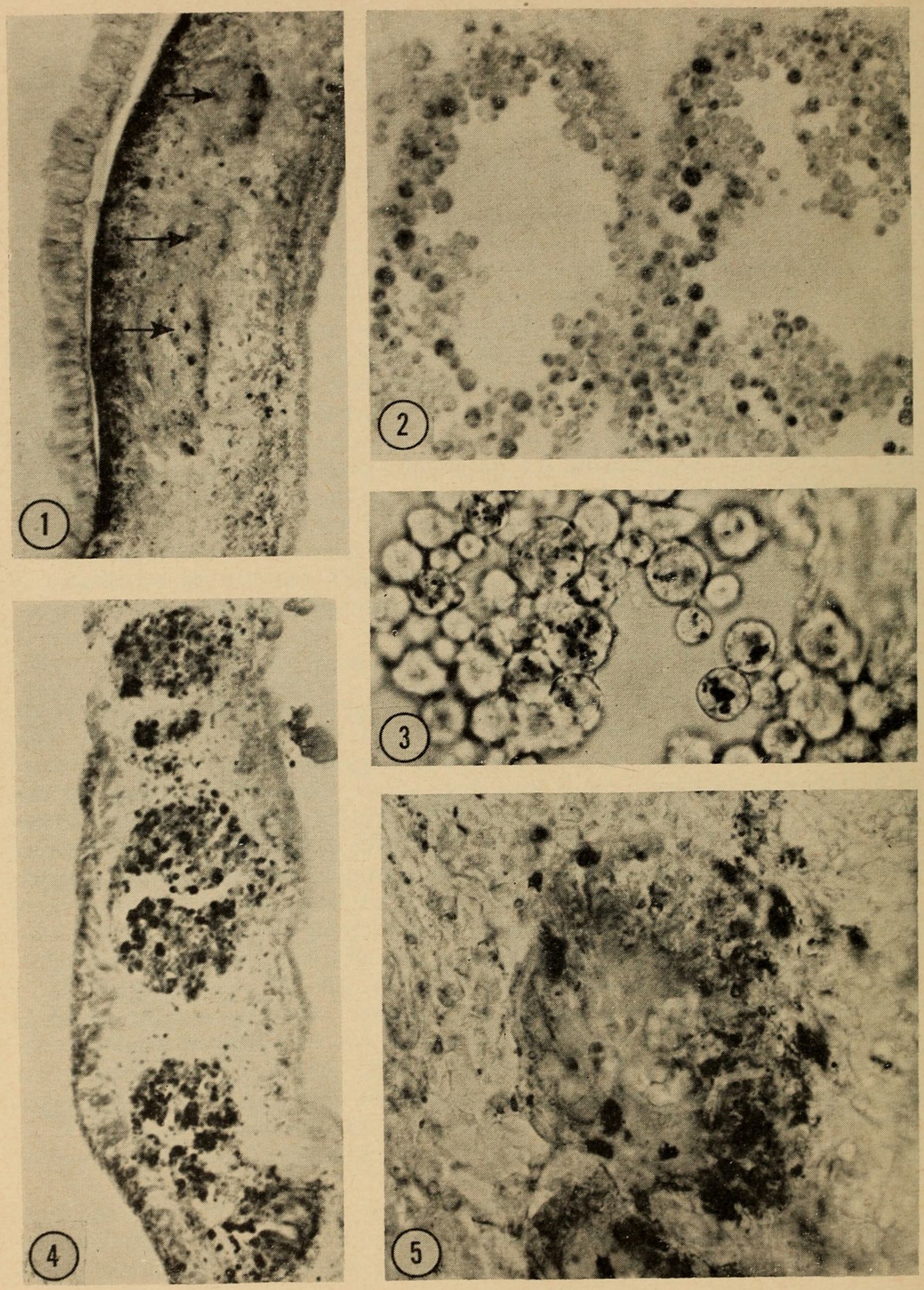

Figures 1-5. 
hours in a vacuum $\left(10^{-3} \mathrm{~mm} . \mathrm{Hg}\right)$ at $-28^{\circ} \mathrm{C}$. and infiltrated for 30 minutes with $54-56^{\circ} \mathrm{C}$. paraffin. Paraffin sections cut at $8 \mu$ were incubated at $37^{\circ} \mathrm{C}$. in substrates consisting of either L-leucyl- $\beta$-naphthylamide (LNA) or L-alanyl- $\beta$ naphthylamide (ANA) buffered to $\mathrm{pH} 7.1$ with $0.2 M$ Tris buffer. Control sections were incubated in a solution of $\beta$-naphthylamine in $0.2 M$ Tris buffer. Garnet GBC or Fast Corinth Salt V were employed as simultaneous couplers in the incubation medium.

$\beta$-glucuronidase activity was demonstrated by the method of Billett and McGeeRussell (1955). It was not possible to achieve a precise intracellular localization of the final ferric-8-hydroxyquinoline crystals with formalin-fixed frozen sections. As an alternative, the entire worm was placed in quinolyl-8-glucuronide at $\mathrm{pH}$ 4.2-4.5 and incubated in the presence of a saturated ferric-8-hydroxyquinoline solution at $37^{\circ} \mathrm{C}$. for 24 hours, following which they were washed, first in distilled water, then in oxalate buffer and finally mounted in toto in glycerine jelly.

\section{Results}

\section{Histology of the gastrodermis}

The gastrodermis consists of a single layer of epithelial cells resting on a delicate basement membrane. Two distinct cell types are present. The phagocytic cell is the larger, the more numerous and contains a basal nucleus and a free end that protrudes into the gut lumen. The cytoplasm is basophilic and has a varying number of eosinophilic inclusions that progressively disappear after feeding. These presumably represent the contents of food vacuoles undergoing digestion (Willier, Hyman and Rifenburgh, 1925).

The second cell type is smaller and less columnar than the phagocyte although its shape varies considerably, depending on the nutritive state of the animal. It has been variously described as a storage, gland or spherical cell and contains intensely staining eosinophilic bodies generally considered to be a protein reserve. The morphology of these two cell types throughout the digestive process has been considered in detail by Willier, Hyman and Rifenburgh (1925).

\section{Acid phosphatase}

No activity was detected in any of the cells comprising the gastrodermis of starved animals (Fig. 1). Due to the presence of diffuse brown-black pigment

Figure 1. D. dorotocephala. Starved (14 days) animal showing three segments of digestive tract (arrows). There is no activity in the gastrodermis. A number of pigmented cells are seen, as well as abundant pigment in the dorsal epidermis. Gomori lead sulfide reaction incubated for 30 minutes at $\mathrm{pH} 4.5$. $100 \times$.

Figure 2. D. dorotocephala, gastrodermis 6 hours post-feeding. There is acid phosphatase activity in many of the food vacuoles but not all cells are equally reactive. $420 \times$.

Figure 3. Acid phosphatase activity in fragments of gastrodermis from $D$. tigrina fed 5 minutes previously. There is a distinct precipitation of lead sulfide within the vacuoles of the phagocytic cells which in some cases have become rounded during maceration. $620 \times$.

Figure 4. Acid phosphatase activity in the gastrodermis of D. dorotocephala 24 hours after feeding. Notice the intense staining in the food vacuoles of the phagocytic cells. A weaker reaction is evident throughout the gastrodermis. $100 \times$.

Figure 5. Section of gastrodermis from D. dorotocephala 10 days after feeding. There is some acid phosphatase activity in the cytoplasm but no food vacuoles are present. Several pigment cells are evident. $420 \times$. 

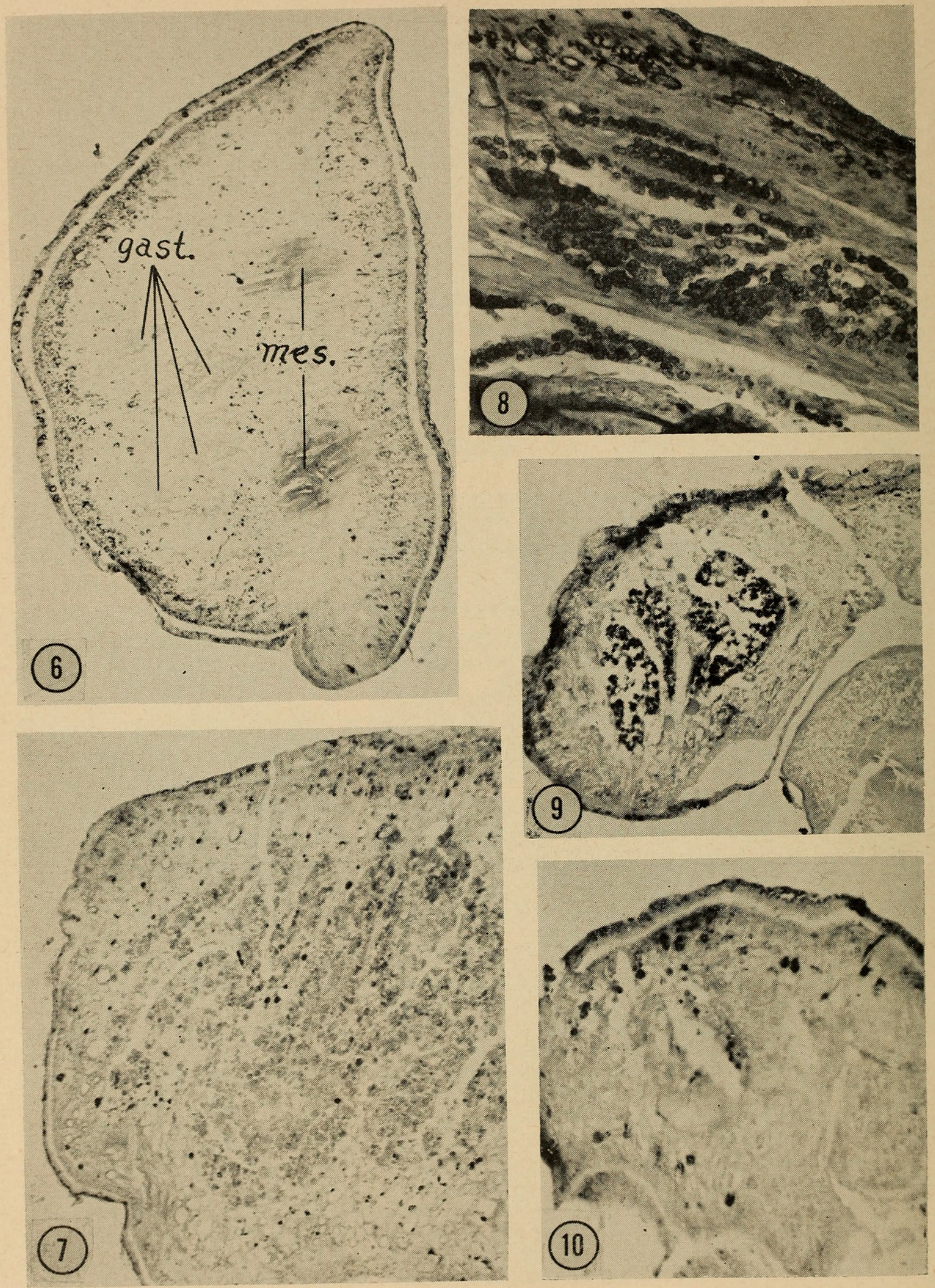

Figures 6-9. 
throughout the animal, controls were necessary to distinguish such pigment from the similarly colored deposits of lead sulfide in a positive enzyme reaction. Sections serving as controls were either heated in a water bath at $60^{\circ} \mathrm{C}$. for 45 minutes or incubated in buffer without glycerophosphate.

Some enzymatic activity could be detected in sections of animals fed 30 minutes previously. The gastrodermis of animals killed six to twelve hours after feeding showed distinct acid phosphatase activity. Activity was localized within vacuoles formed in the phagocytic cells (Fig. 2), but the intensity of the reaction varied considerably from vacuole to vacuole. Such differences in enzyme activity are presumably dependent on the amount of material phagocytized, the length of time the food has been in the vacuole and, hence, the extent of digestion taking place in the vacuole at the time of fixation.

Attempts were made to visualize the intracellular distribution of acid phosphatase during formation of the food vacuoles. Since frozen sections did not provide optimal preservation of cytological details, a series of small animals, fed approximately 30 minutes previously, were squashed on chilled coverslips and immediately fixed in cold calcium-formalin. These preparations were then incubated in buffered ( $\mathrm{pH} 4.8$ ) glycerophosphate and acid phosphatase activity visualized by precipitated lead sulphide. As early as five minutes after initiation of feeding, acid phosphatase could be demonstrated within newly forming food vacuoles (Fig. 3). During formation of the food vacuole, the sites of enzyme activity are discrete but of varying size depending on the physiological activity of the vacuole. Four to six hours after feeding, most vacuoles showed such intense acid phosphatase activity that the entire vacuolar space was filled by a lead sulphide precipitate. No cytoplasmic enzyme activity could be detected at this time.

Twenty-four hours after feeding, intense acid phosphatase activity occurred throughout the gastrodermis (Fig. 4). While staining was still most striking within the food vacuoles, a reaction also occurred in the cytoplasm of the columnar cells. In all instances, this was limited to the gastrodermis with no staining demonstrable in the mesenchyme (Fig. 4). This activity, both in vacuoles and cytoplasm, persisted up to 48 hours, following which a gradual diminution became evident.

One week after feeding, a few cells in gastrodermis showed slight staining for enzymatic activity (Fig. 5).

Figure 6. D. dorotocephala, starved for two weeks and incubated in L-leucyl- $\beta$ naphthylamide for aminopeptidase activity. There is no staining in the gastrodermis (gast.) but two regions in the mesenchyme (mes.) show enzyme activity. Numerous pigment cells are present throughout the section, especially in the dorsal epithelium. Photographed in combination with Corning narrow band filters, Nos. 3486, 9782 and 5120. $100 \times$.

FIGURE 7. Aminopeptidase activity in the gastrodermis of $D$. dorotocephala 30 minutes after feeding. Staining is not uniform but its localization within vacuoles is evident. $210 \times$

FigURE 8. Aminopeptidase activity localized within vacuoles in the gastrodermis of D. dorotocephala 12 hours after feeding. There is no reaction in the cytoplasm of the phagocytic cells. $460 \times$.

FigURE 9. Aminopeptidase activity in the gastrodermis of $D$. dorotocephala. The picture is typical of the reaction in animals 24 to 48 hours after feeding. $160 \times$. $160 \times$

FIGURE 10. D. dorotocephala starved for 10 days. No aminopeptidase activity is present. 


\section{Aminopeptidases}

Although both leucyl- and alanyl-derived substrates were employed, it was impossible to distinguish differences in activity between the two substrates. The $\mathrm{pH}$ optima (7.0-7.6) and optimal incubation times for both substrates were also identical. Only slight activity was obtained with both substrates at a more acid $\mathrm{pH}(4.5-5.0)$.

There was some aminopeptidase activity in the mesenchyme of starved animals although none could be detected in the gastrodermis (Fig. 6). The presence of enzyme in the mesenchyme of starved animals was probably related to a lowered nutritional state since an increase in enzyme activity in the mesenchyme of animals starved for two, four or six weeks, respectively, was always observed. This suggests that a mechanism is present outside the gastrodermis for utilization of the animals' tissues as a food reserve. The ability of planarians to withstand long periods of starvation with a corresponding reduction in body size is well known.

Aminopeptidase activity was detected in the gastrodermis 30 minutes after feeding (Fig. 7). The staining appeared strongest in those cells possessing the largest food vacuoles and, hence, undergoing most active phagocytosis.

Twelve hours after feeding, nearly all the phagocytic cells of the gastrodermis contained food vacuoles which stained positively for aminopeptidases (Fig. 8). Staining was most intense 24 to 48 hours after feeding. (Fig. 9), following which there was a rapid decline in activity throughout the gastrodermis.

Seven days after feeding (Fig. 10), no reaction for aminopeptidase was obtained in the gastrodermis. At this stage, some cells in the mesenchyme did possess a positive reaction for these enzymes (Fig. 10). This appears to support the observation of Jennings (1957), that phagocytosed material can pass back into the mesenchyme for subsequent digestion.

\section{Beta-glucuronidase}

The method originally suggested by Billett and McGee-Russell (1955) for the demonstration of $\beta$-glucuronidase was not satisfactory for fresh-frozen sections of planarians. Even tissue from animals fixed for three hours in cold neutral formalin did not satisfactorily withstand incubation in quinolyl-8-glucuronide at $\mathrm{pH} 4.0-4.5$. Since intracellular localization of the enzyme could not be obtained in sections, it was decided to use the in toto incubation method employed by Billett and Mulherkar (1958) for the chick embryo. Small, recently fed worms were fixed in cold neutral formalin for three hours. They were then thoroughly washed in several changes of cold distilled water and incubated in quinolyl-8-glucuronide for 24 hours at $37^{\circ} \mathrm{C}$. as previously described. Control animals were incubated in substrate to which $0.0005 M$ potassium acid saccharate had been added as an inhibitor. The presence of ferric-8-hydroxyquinoline crystals could be detected in the gut of animals 24 or 48 hours after feeding. No similar reaction was obtained in the gut of starved animals. Although the technique employed for $\beta$-glucuronidase was not satisfactory from the standpoint of intracellular localization, it did demonstrate the presence of $\beta$-glucuronidase activity parallel in time to the appearance of acid phosphatase and aminopeptidase. 


\section{Discussion}

While a considerable amount of investigative work has been undertaken on intracellular digestion following phagocytosis or pinocytosis in organisms such as Ameba, little is known about the digestive enzymes present in other invertebrates (Kitching, 1956). In the present reports, the localization of specific hydrolytic enzymes in some fresh-water triclads has been demonstrated in relation to the food vacuoles formed within phagocytic cells in the gastrodermis.

The acid environment within food vacuoles has long been known and it has been assumed that this is related to the function of the digestive process. The $\mathrm{pH}$ optima of acid phosphatase and $\beta$-glucuronidase are approximately the same (4.2-4.6). Jennings (1957) has obtained a value of $\mathrm{pH} 4.6$ in the food vacuole of the triclad, Polycelis, six hours after feeding. Our own data (unpublished) show similar values for Dugesia.

It has not been sufficiently emphasized that aminopeptidase activity, identified by the methods employed here, does not ipso facto demonstrate the leucine aminopeptidase considered as a single enzyme by Smith and Spackman (1955). Other peptidases are capable of splitting leucyl peptides (Fleisher, 1954) and it is therefore necessary to assume caution regarding the degree of specificity obtained by the present methods. The similarities, both in the degree and distribution of enzyme activity as well as $\mathrm{pH}$ optima, obtained with the substrates LNA and ANA in the present investigation, suggest that we are dealing with such a lack in specificity. Recently, Waldschmidt-Leitz and Keller (1957) have demonstrated that "leucine" aminopeptidase is a mixture of peptidases and does not represent a specific enzyme. The histochemical significance of this problem has been considered in detail by Glenner et al. (1959).

It is interesting to consider the possible mechanisms responsible for release of enzymatic activity following feeding. The observation that the three enzymes studied here appear after the majority of food vacuoles have formed suggests a secretion of enzymes from the cytoplasm into the vacuole. An alternative mechanism would call for the de novo synthesis of enzymes within the forming vacuole but then one would expect to find enzymatic activity appearing along with the earliest formation of the food vacuole. Some evidence for the secretion of enzymes from cytoplasm into vacuoles has come from observations of the microkinetospheres of certain cell variants of HeLa cultures (Rose, 1957). The localization of acid phosphatase activity throughout the gastrodermis 24 to 48 hours after feeding indicates that the cytoplasm of these cells possesses the capacity to synthesize the enzyme. There is evidence from the present observations that aminopeptidase is similarly localized in the cytoplasm of cells. In starved animals, for example, activity was found in the mesenchyme and the possibility that such sites may represent localized digestion of the animals' own tissue-perhaps for nutritive purposes-has been mentioned.

The three enzymes studied represent a class of six or more soluble acid hydrolases collectively associated with a group of cytoplasmic particles termed "lysosomes" by de Duve (1959). Although the lysosome concept has been investigated most thoroughly in the liver cell, there is increasing evidence that these particles may be concerned with localized phenomena related to the acid digestion 
of cells in general. Evidence for this is available from observations on Ameba (Bennett, 1956) ; spleen macrophages (Palade, 1956) and, most conclusively, in "athrocytosis" phenomena in kidney cells (Straus, 1957).

\section{SUMMARY}

1. The presence of the three hydrolytic enzymes, acid phosphatase, aminopeptidase and $\beta$-glucuronidase have been demonstrated in relation to digestion phenomena in Dugesia dorotocephala and D. tigrina.

2. None of these enzymes were detected in the gastrodermis of starved animals. Acid phosphatase activity appears 5 minutes after feeding commences and is closely identified with formation of the food vacuoles. Maximum phosphatase activity is present in all vacuoles 24 to 48 hours after feeding; a slight reaction occurs in the cytoplasm of all gastrodermal cells at this time. Three days after feeding, acid phosphatase activity declines until one week after feeding, no activity is evident.

3. Aminopeptidase activity is present in the mesenchyme of starved animals where it is probably associated with "self-digestion" phenomena related to the nutritional state of the animal. In general, aminopeptidase activity parallels that of acid phosphatase. While intracellular localization of $\beta$-glucuronidase was not achieved, its activity in the digestive tract was observed to be similar to that of the other two enzymes studied.

4. The results obtained on a histochemical level are discussed in terms of current concepts of the mechanism of intracellular digestion.

\section{LITERATURE CITED}

ArNold, G., 1909. Intra-cellular and general digestive processes in Planariae. Quart. J. Micr. Sci., 54: 207-220.

Bennett, H. S., 1956. A suggestion as to the nature of the lysosome granule. J. Biophys. Biochem. Cytol., 2 Suppl.: 185.

Billett, F., And S. M. McGeE-Russell, 1955. The histochemical localization of $\beta$-glucuronidase in the digestive gland of the Roman snail (Helix pomatia). Quart. J. Micr. Sci., 96: $35-48$.

Billett, F., And L. Mulherkar, 1958. The localization of $\beta$-glucuronidase in the early chick embryo. J. Embry. Exp. Morph., 6: 52-56.

Burstone, M. S., And J. E. Folk, 1956. Histochemical demonstration of aminopeptidase. J. Histochem. Cytochem., 4: 217-226.

DE Duve, C., 1959. Lysosomes, a new group of cytoplasmic particles. In: "Subcellular Particles," ed. by T. Hayashi. Ronald Press, New York.

Fleisher, G. A., 1954. Peptidase in human blood. II. The hydrolysis of additional peptides by normal serum. J. Biol. Chem., 206: 637-640.

Glenner, G. G., M. S. Burstone And D. B. Meyer, 1959. A study of aminopeptidase activity in the stroma of neoplastic tissue, with a comparison of histochemical techniques. J. Nat. Cancer Inst., 23: 857-873.

Gomori, G., 1952. Microscopic Histochemistry. Univ. of Chicago Press, Chicago.

JACEK, S., 1917. Untersuchungen über den Stoffwechsel bei rhabdocoelen Turbellarien (Stenostomum). Bull. Int. Acad. Sci. Cracovie, 8(B): 241-261.

Jennings, J. B., 1957. Studies on feeding, digestion and food storage in free-living flatworms. (Platyhelminthes: Turbellaria). Biol. Bull., 112: 63-68.

Kelley, E. G., 1931. The intracellular digestion of thymus nucleoprotein in triclad flatworms. Physiol. Zoöl., 4: 515-541.

Kitching, J. A., 1956. Food vacuoles. Protoplasmatologia, vol. III, part D3b. Springer, Vienna; pp. 1-54. 
von Levitzow, K. G., 1943. Zur Biologie und Vedauungsphysiologie der polycladen Turbellarien. Zool. Anz., 141: 189-196.

Palade, G. E., 1956. The endoplasmic reticulum. J. Biophys. Biochem. Cytol., 2 Suppl.: 85-98.

Rose, G. G., 1957. Microkinetospheres in VP satellites of pinocytic cells observed in tissue culture of Geys strain HeLa with phase contrast cinematographic techniques. $J$. Biophys. Biochem. Cytol., 3: 697-704.

Saint-Hilaire, C., 1910. Beobachtungen über die intracelluläre Verdauung in den Darmzellen der Planarian. Zeitschr. allg. Physiol., 11: 177-248.

Smith, E. L., And D. H. Spachman, 1955. Leucine aminopeptidase. V. Activation, specificity and mechanism of action. J. Biol. Chem., 212: 271-299.

Straus, W., 1957. Changes in "droplet" fractions from rat kidney cells after peritoneal injection of egg white. J. Biophys. Biochem. Cytol., 3: 933-947.

Waldschmidt-Leitz, E., and L. Keller, 1957. Zur Frage der Existenz einer Leucyl-peptidase. Zeitschr. physiol. Chem., 309: 228-238.

Willier, B. H., L. H. Hyman and S. A. Rifenburgh, 1925. A histochemical study of intracellular digestion in triclad flatworms. J. Morph. Physiol., 40: 299-340. 


\section{$2 \mathrm{BHL}$ Biodiversity Heritage Library}

Rosenbaum, Robert M and Rolon, Carmen I. 1960. "Intracellular digestion and hydrolytic enzymes in the phagocytes of planarians." The Biological bulletin 118, 315-323. https://doi.org/10.2307/1539005.

View This Item Online: https://www.biodiversitylibrary.org/item/110976

DOI: https://doi.org/10.2307/1539005

Permalink: https://www.biodiversitylibrary.org/partpdf/2138

\section{Holding Institution}

Smithsonian Libraries

\section{Sponsored by}

Biodiversity Heritage Library

\section{Copyright \& Reuse}

Copyright Status: In copyright. Digitized with the permission of the rights holder.

License: http://creativecommons.org/licenses/by-nc-sa/3.0/

Rights: https://biodiversitylibrary.org/permissions

This document was created from content at the Biodiversity Heritage Library, the world's largest open access digital library for biodiversity literature and archives. Visit BHL at https://www.biodiversitylibrary.org. 